\title{
Correction to: Real options theory in international business
}

\author{
Tailan $\mathrm{Chi}^{1}$, Jing $\mathrm{Li}^{2}$, \\ Lenos G Trigeorgis ${ }^{3,5}$ and \\ Andrianos E Tsekrekos ${ }^{4}$
}

${ }^{1}$ School of Business, University of Kansas, 1654 Naismith Dr, Lawrence, KS 66045, USA; ${ }^{2}$ Beedie School of Business, Simon Fraser University, 8888 University Drive, Burnaby, BC V5A 156, Canada; ${ }^{3}$ Department of Accounting and Financial Management, King's Business School, King's College London, Bush House (N)3.01, 30 Aldwych Street, London WC2B 4BG, UK; ${ }^{4}$ Department of Accounting and Finance, Athens University of Economics and Business (A.U.E.B.), 76 Patision Street, 10434 Athens, Greece; ${ }^{5}$ School of Economics and Management, University of Cyprus, 75 Kallipoleos, 1678 Nicosia, Cyprus

Correspondence:

T Chi, School of Business, University of Kansas, 1654 Naismith Dr, Lawrence, KS 66045, USA.

Tel: 1-785-864-7593;

e-mail: chi@ku.edu
Journal of International Business Studies (2019) 50, 554.

https://doi.org/ | 0.1057/s4 I 267-019-00227-7

\section{CORRECTION TO: JOURNAL OF INTERNATIONAL BUSINESS STUDIES (2019) https://doi.org/10.1057/s41267-019-00222-y}

The original version of this paper was inadvertently published without one of the co-authors' affiliations. Lenos G. Trigeorgis has an additional affiliation as follows:

School of Economics and Management, University of Cyprus, 75 Kallipoleos, 1678 Nicosia, Cyprus.

Publisher's Note Springer Nature remains neutral with regard to jurisdictional claims in published maps and institutional affiliations. 